\title{
Widening access to higher education for low-income students: a Brazilian case study (1990s-2016)
}

LEONARDO CIVINELLI TORNEL DA SILVEIRA Universidade de Lisboa, Lisboa, Portugal

\section{ABSTRACT}

This article analyses the widening access policies implemented by Brazil during the 1990s and in 2016. It cites and evaluates the different strategies used by the government, such as student loans, needs-based and race-based quotas. In the context of a highly privatized sector, in which for-profit higher education institutions account for over half of the existing higher education institutions in Brazil, the results display a relative growth in higher education access based on minorities and needs-based communities. However, it also showcases some trends not achieved as originally planned by the government (specially increasing higher education participation in regions other than the south and the southeast) and serves as a point requiring further research to evaluate the influence on the lives of students and graduates. This study uses government and publicly available sources to analyse the impact of this strategy over time.

\section{KEYWORDS}

inclusiveness; widening participation in higher education; privatisation. 


\section{AUMENTO DO ACESSO AO ENSINO SUPERIOR PARA ESTUDANTES DE BAIXA RENDA: UM ESTUDO DE CASO BRASILEIRO (1990-2016)}

\section{RESUMO}

$\mathrm{O}$ artigo analisa as amplas políticas de acesso implementadas no Brasil na década de 1990 e em 2016. Ele cita e avalia as diferentes estratégias usadas pelo governo, tais como empréstimos estudantis, cotas baseadas em necessidade e etnia. Em um contexto de setor altamente privatizado, no qual instituições de ensino superior com fins lucrativos representam a maioria das instituições de ensino existentes no Brasil, os resultados apresentam um crescimento relativo no acesso à educação superior baseado na integração da população de diversas etnias e com necessidades. No entanto, também apresenta alguns objetivos que não foram alcançados como o governo tinha planejado (especialmente no aumento da participação de ensino superior em outras regiões além do Sul e Sudeste do país). O artigo também reforça a necessidade de mais pesquisas para avaliar as influências do ensino superior na vida dos alunos e egressos. $\mathrm{O}$ artigo utiliza fontes governamentais e publicamente disponíveis para analisar a estratégia ao longo do tempo.

\section{PALAVRAS-CHAVE}

inclusão; ampliação da participação no ensino superior; privatização.

\section{AMPLIACIÓN DEL ACCESO A LA EDUCACIÓN SUPERIOR PARA ESTUDIANTES DE BAJOS INGRESOS: UN ESTUDIO DE CASO BRASILEÑO (1990-2016)}

\section{RESUMEN}

Este artículo analiza la ampliación de las políticas de acceso implementadas por Brasil durante los años 1990 y en 2016. Cita y evalúa las diferentes estrategias utilizadas por el gobierno, tales como préstamos estudiantiles, cuotas basadas en las necesidades y cuotas basadas en la raza. En un contexto de un sector altamente privatizado, en el que las instituciones de educación superior lucrativas representan más de la mitad de todas existentes en Brasil, los resultados muestran un crecimiento relativo en el acceso a la educación superior basado en las minorías y comunidades más necesitadas. Sin embargo, también muestra algunas tendencias que no se alcanzaron como se había planeado (especialmente en el aumento de la participación de enseñanza superior en otras regiones que el Sur y el Sureste) y sirve como un punto que require mayor investigación para evaluar las influencias del enseñanza superior en la vida de los estudiantes y graduados. El estudio utiliza fuentes gubernamentales y públicas para analizar el impacto de la estrategia en el tiempo.

inclusividad; ampliar la participación en la educación superior; privatización. 


\section{INTRODUCTION}

Since the 1990s, the sector of higher education has been discussing the theme of universal access. The neoliberal approach prioritised the privatisation of higher education provision in developing countries and increased the participation of the private sector as a key player to widen the access to higher education institutions to a variety of audiences. It specifically defended the necessity of these institutions entering the market in an international crisis context to make universities accessible to a bigger percentage of the population.

One of the most important case studies to be observed may be Brazil. A key player in Latin America, a rapidly developing country in the first decade of the twenty-first century, and a country studied worldwide for its public policies on how to lower social inequalities, and combat hunger and poverty among its population. Similar initiatives have been introduced in the last twenty years in higher education: the quotas for low-income and ethnic minority background students in public universities, state-funded scholarships for students in private institutions with Programme University for All (PROUNI), the National Education Plan (PNE, in Portuguese) incentives for privatisation and, finally, the Fund for Financing Higher Education Students (FIES), ${ }^{1}$ a state-funded loan strategy to widen the access of low-income students to private institutions. The results of this growth will be the focus of this study. Brazil is a special scenario, because the latest national census indicated that over $85 \%$ of all higher education institutions are considered private institutions, which registered over 8 million new higher education institution students in 2015 (INEP, 2016).

The main aim of the study is to answer to the following guiding research questions: What changed in the Brazilian higher education landscapes during this period? and What were the most significant implications observed (demographically and conceptually) that may arise from these changes? The study uses data made public from the Ministry of Education (MEC) and from the Brazilian Government and internationally publicly available reports from the World Bank and from the International Monetary Fund (IMF) to compile its analysis.

The study will first consider the definitions of inequality and its generated tensions, especially the challenges arising for low-income individuals; second, it will focus on the role of higher education in society. The third part of the study will summarise strategically the socioeconomic and educational context of Brazil. The fourth part will be dedicated to a case study about the four initiatives described previously, and the main government strategies used to widen the participation of low-income students in higher education institution. The fifth section will be a discussion about the consequences and development that the practice of widening participation brought to education in Brazil. The last part of this study is the conclusion of the analysis.

1 Fundo de Financiamento Estudantil, in Portuguese, author's translation to English. 


\section{COMPREHENDING INEQUALITY: THE CHALLENGES FOR LOW-INCOME INDIVIDUALS}

The first two parts of this study are important to contextualise the kind of inequality we will refer to whenever we cite this term. They provide a way to understand the challenges low-income individuals encounter in society, and explain the current tensions about the role of higher education in social mobility, and universal access.

Perhaps the most important question to start this work with is: what is inequality? What challenges does it create for individuals? This study will focus on income inequality because this is the factor that most relates to the Brazilian policies' application.

A crucial characteristic of capitalism, and specifically the neoliberal approach, is to accept people as individuals. The participation of the state is limited to regulating and providing the conditions for markets to prosper, while on an individual level meritocracy and freedom of choice are regarded as two of the most relevant values. As a direct derivation of such values, it is part of a capitalist society to embrace income inequality as part of the system.

For Rawls (1999), a political scientist interested in social justice, income inequality is not necessarily a bad thing. Rawls describes some of the arguments used by those who advocate the idea: it enables meritocracy to operate, accepting the fact that some people deserve to earn more due to their own achievements; it supports the competitive orientation of markets, creating a continuous flow of change in supply and demand dynamics; and it is seen as part of human nature, as individuals are free to have different interests and motivations to invest their own resources. In Rawls' view, inequalities in economic and social status can be justified to the extent that they serve the interests of the least-fortunate class in society, but not otherwise.

Harland (2009) adds that in the neoliberal approach (popularised in the 1970s through a series of economic and political reforms), income inequality should not be seen as a problem as long as a state is competent enough to avoid poverty invading its socioeconomic system by ensuring basic human rights.

Education is considered by the United Nations (1948) as "a basic right for human society". Its role is directly related to the possibility of upward mobility supported by the neoliberal meritocratic and self-driven society. Access to education has for a long time been connected to gaining access to a wider range of professional opportunities, earning bigger salaries, changing one's position on the dynamics of society and creating new protagonists for the capitalist storytelling.

However, it is clear that there is a certain level of income inequality, which creates unfair competition between individuals, who, theoretically, should be in similar positions to succeed in the neoliberal context. The Organisation for Economic Co-Operation and Development (OECD) report (2014, p. 18) suggests that rising inequality cut more than ten percentage points off gross domestic product (GDP) growth in countries such as New Zealand and Mexico. In the United Kingdom and the United States of America, growth rates would have been more 
than one-fifth higher had income disparities not widened (OECD, 2014, p. 18). One of the reasons suggested is that low-income individuals may have to sacrifice investments in non-living expenses, such as their own education (OECD, 2014, p. 24). The result is that there is a lack of efficiency in the market as there are gaps in the production of professionals to execute tasks effectively; the outcomes of the industry subsequently drop and low-income salaries inhibit consumerism, driving a cycle of lower supply and demand.

The report also suggests that living in a highly unequal society in which neither of an individual's parents attended university, means the probability of that person completing tertiary education can be more than four times lower than a scenario in which both parents attended university and there are low inequality rates in society (OECD, 2014, p. 25). Where both of an individual's parents did not complete tertiary education, doubling the inequality rate would reduce to less than half that individual's probability of completing tertiary education.

The IMF report $(2014$, p. i) is emphatically suggesting that redistribution efforts - essential to fight inequality - are good for growth is a welcome finding. Low tax and low public spending are clearly not the route to prosperity. A previous study in 2011 by the World Bank also stated that less inequality increased the duration of countries' economic growth more than free trade, low government corruption, foreign investment or low foreign debt (World Bank, 2011).

In this study, income inequality will be considered an undeniable fact of the foundations of the capitalist economy; yet education will be considered a tool for social mobility and a basic human right, which will work as a democratic opportunity to develop individuals' skills despite their social class or economic background. The next section will examine the role of higher education in such a scenario.

\section{THE ROLE OF HIGHER EDUCATION IN SOCIETY}

This section will explore the role of higher education in the context of the current neoliberal society. The focus of the section will be particularly on the situation of developing countries such as Brazil.

Harland (2009) claims that the history of universities shows that both recent and ancient institutions in higher education have faced radical changes that transformed them over time; thus it would be impossible to analyse the role of universities without citing the influence of the current transformation caused in the 1970s with the adoption of neoliberal political and economic reforms.

The changes caused in the international context mitigated the investment of the United States and United Kingdom economies in developing countries' education and diminished the influence of international organisations, such as United Nations Educational, Scientific and Cultural Organization (UNESCO), in the development of national educational systems (McCowan, 2004). The World Bank can be considered the biggest source of investment nowadays for countries in development countries (Leher, 1999). The World Bank among the low and middle-income countries (LMICs) classifies countries like Brazil. LMICs tend to be extremely dependent on World Bank loans to develop their educational systems 
and these loans are quite often connected to some sort of demands, which may affect the role of higher education in practice.

For example, one of the creeds of the World Bank is that higher education worldwide is in the middle of a crisis, in which even the high-income countries are struggling to cope with rising enrolments and research costs (McCowan, 2004). The 1994 World Bank report reinforced the idea that despite finance as a main concern, there are equally important preoccupations with quality in a context of rising enrolment, and equity of access for a larger share of society.

Thus, the recommendation of the World Bank $(1994$, p. 36) is to concentrate state funding in basic education and create stimulation for the private sector to absorb the increasing demand for higher education. This situation occurs because the World Bank considers the investment in higher education as one which contributes less to social equity and has lower economic returns than basic education access. The same hypothesis is supported by the United Nations Declaration of Human Rights (1948), which advocates the idea that basic education for all should be the priority of government strategies in LMIC contexts.

The idea of private provision for higher education is based on three main arguments (McCowan, 2004, p. 455):

1. Private sector involvement will increase the number of places in higher education, thus widening access and increasing equity.

2. The traditional model of the European research university is inappropriate for LMICs and for the modern economy. Private universities can provide an education more suited to students' needs, and competition between them will increase quality.

3. Private sector involvement will provide higher education at little public cost.

Despite the benefits of private provision, there are ranges of consequences that threaten the achievement of higher education institutions role in society as some authors conceive it. For example, in the past it was possible to observe that the universities acted to enable social change through meritocracy and opportunity for a wider range of people, and are part of the core of the debate that constructs a democratic society (Harris, 2005).

The neoliberal approach was seen to shift power from the public to the private sphere, turning even the public universities into an instrument to serve the needs of market demands (Harland, 2009, p. 514). Knowledge is becoming an increasingly privatised commodity, and that unregulated search for profit is changing the way universities are accountable to the external environment and judged more and more by rankings and tables that focus on the managerial aspects of education (Harland, 2009).

Hence, the irrevocable role of education as a tool for social mobility must be highlighted as one of the key roles of the neoliberal society. The necessity of widening access to higher education and providing democratic opportunities are part of the core of the system's dynamics. The study will now examine the context of Brazil and then focus on the case study of FIES to enhance the aforementioned access. 


\section{THE BRAZILIAN CONTEXT}

In this section, the study will briefly introduce the socioeconomic and political characteristics of Brazil and summarise the changes in higher education throughout the 26 years analysed.

\section{BRAZIL: HIGHLIGHTS OF THE SOCIOECONOMIC AND POLITICAL CONTEXT}

Brazil is one of the five most populated countries in the world, with an estimate of just over 200 million people in 2014 (IBGE, 2010). Its GDP is a little bit over 3.2 trillion USD (IMF, 2015), which corresponds to the seventh biggest economy in the world. Its Growing Inequalities' Impacts coefficient (GINI) (the World Bank mathematical formula that calculates the income inequality in a country) is 51 points, considered "high" by the standards of the methodology (World Bank, 2011). Brazil is historically known for its continental area (over 8.5 million square $\mathrm{km}$ - the fifth largest country in the world) and its diverse population, with an intense mix of ethnicities and cultures around the country. The main ethnic groups are white (47\%), brown (43\%) and blackskinned (7\%) (IBGE, 2010).

From 1994 to 2002, Fernando Henrique Cardoso, a former minister who created Plano Real, a series of economic measures that controlled inflation and decades of economic instability under a military dictatorship, ruled Brazil. His period was known as the era of privatisation: state owned companies, like the giant Petrobras, were open to private capital. The principle had a huge impact on higher education.

From 2002 to 2010, Luiz Inácio Lula da Silva ruled Brazil; he was a former metallurgic and socialist leader, and a member of the Worker's Party. Lula enjoyed great popularity, especially for his social measures to increase the participation of low-income people in the economy and eradicate poverty in vulnerable communities. These actions had a high impact on the participation of low-income people in higher education, and form part of the case study in the next section.

From 2010 until 2016, Dilma Rousseff, the first woman in history to be elected president, ruled Brazil. Despite being part of the same Party as Lula, Dilma struggled with corruption scandals and civil riots (two examples would be the widely known Mensalã $0^{2}$ and the World Cup protests). ${ }^{3}$ Nonetheless, Rousseff was re-elected at the end of 2014, and maintained the same policy of increasing the participation of low-income people in government until her impeachment in 2016; under president Michel Temer (2016 - present) it is now allegedly combined with national policies that are fostering overall economic and infrastructural development, although Brazil has been facing a severe economic crisis in the past couple of years.

2 Scheme of bribery and political influence that involved participation and condemnation of high level political figures in the Lula administration.

3 A series of riots and confrontations between citizens and the police protesting against the mismanagement and deviation of resources currently under investigation that over budgeted the 2014 FIFA World Cup in Brazil. 


\section{BRAZIL: OVERALL EDUCATIONAL CONTEXT HIGHLIGHTS}

McCowan (2004, p. 456) argues that the educational system of Brazil is extremely similar to the inequalities that characterise the country as a whole. He claims that while an upper middle-class child is guaranteed an education comparable to that of any developed country, the poor struggle in a system in which the effects go way beyond a few years at an unresourced primary school.

There is robust data that supports such viewpoint. The last national census, registered in 2010 by the National Institute of Geography and Statistics (IBGE, 2010), shows that illiteracy still affects $8.7 \%$ of its overall population (UNESCO, 2012). According to the 2012 Programme for International Student Assessment (PISA) organised by the internationally recognised OECD, Brazil is ranked in the 55 th position in reading, 58th in mathematics and 59th in sciences, quite disturbing results considering that the total number of countries analysed was 65 (OECD, 2012).

The disparities are also shown in the regional results in education. While in the southeast region, in which is concentrated the biggest share of the GDP (IMF, 2014) and the population of Brazil (IBGE, 2010), the rate of illiteracy is considerably lower than the national average (8.7\%); the same rate is $19.9 \%$ in the Northeast region (PNAD, 2007), known for one of the lowest Human Development Index scores in the country (IBGE, 2010). The time people ten years of age or older spend in school is 6.9 years on average (compared with 12 in the United States, and 8 in Latin American neighbours like Argentina) while the percentage of the Brazilian population that completes secondary education is 22\% (compared with 55\% in Argentina and 82\% in South Korea, for example) (PNAD, 2008).

As seen before, the effects of inequality resonate clearly in the range of opportunities for social mobility. One of the ways that the scope of opportunities can be analysed is by assessing access to higher education, as this can only be accessed by those who have passed through the whole primary and secondary education system. These opportunities represent higher salaries and better jobs for the majority of the people that graduate (IBGE, 2010), and for the economic development of a country (IMF, 2014), as previously indicated.

The Brazilian higher education scenario is a good example of expansion following policies of privatisation and social inclusiveness, and the main reason for this article. As Table 1 shows, The number of people 18-24 years enrolled in higher education jumped from $16.6 \%$ in 2002 to $28.7 \%$ in 2012 .

The results also show some interesting figures, such as the overall predominance of women over men among the aforementioned age enrolled in higher education (33.3\% compared to 24.1\%) (INEP, 2012, p. 38).

In comparison, the score of $28.7 \%$ of higher education population enrolment is below the World Bank global average of 32.1\% and the Latin America and Caribbean average of 43\% (World Bank, 2011). The Graph 1 below compares global results.

Table 2 presents Brazil's outstanding expansion results during the 2003-2012 period. 
Table 1 - Regional higher education enrolment distribution

\begin{tabular}{l|c}
\hline Territory & Higher education population enrolment - 8-24 years old (\%) \\
\hline Brazil & 28.7 \\
\hline Northeast Region & 24.5 \\
\hline North Region & 22.4 \\
\hline Southeast Region & 30.9 \\
\hline South Region & 34.5 \\
\hline Centre-West Region & 35.3 \\
\hline
\end{tabular}

Source: INEP (2012, p. 39).

Author's elaboration.

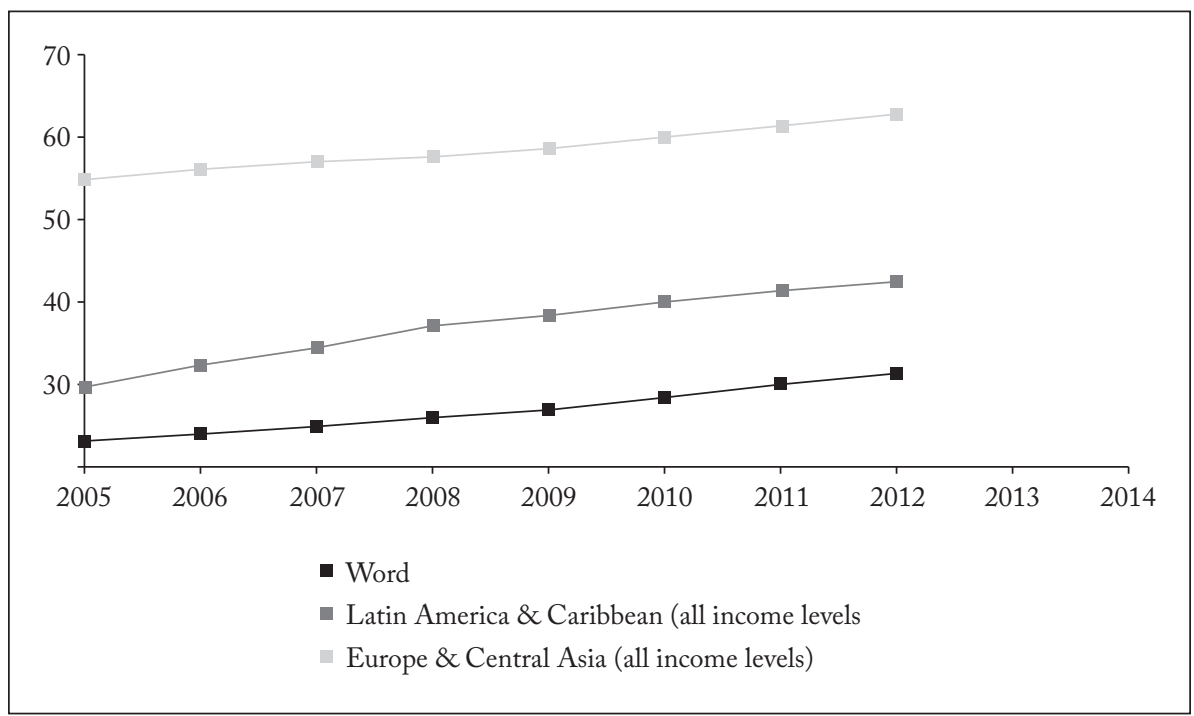

Graph 1 - Adjusted net enrolment rate, upper secondary, both sexes (\%)

Source: Extracted from <http://databank.worldbank.org/data/reports. aspx?Code=SE.TER.ENRR\&id=c755d342\&report_ name=EdStats_Indicators_Report\&populartype=series $>$. Accessed: $18^{\text {th }}$ May 2015.

Table 2 - Enrolment distribution per region (numbers and percentage) 2003-2012

\begin{tabular}{l|c|c|c|c}
\hline Region & $\mathbf{2 0 0 3}$ & of total $(\%)$ & $\mathbf{2 0 1 2}$ & of total (\%) \\
\hline Brazil & $3,887,022$ & 100 & $5,923,838$ & 100 \\
\hline North & 230,227 & 5.9 & 404,727 & 6.8 \\
\hline Northeast & 624,692 & 16.1 & $1,213,519$ & 20.5 \\
\hline Southeast & $1,918,033$ & 49.3 & $2,816,086$ & 47.5 \\
\hline South & 745,164 & 19.2 & 941,738 & 15.9 \\
\hline Centre-West & 368,906 & 9.5 & 547,768 & 9.2 \\
\hline
\end{tabular}

Source: INEP (2012, p. 59).

Author's elaboration. 
The results above show a growth of more than two million people enrolling in universities in a decade. The overall results evolution show an increase in the contribution of the regions with the lowest percentage of the population enrolled in higher education in the national average.

Despite achieving results below the global enrolment average, such expansion is part of a consistent growth strategy of widening access to higher education, especially in the new millennium. There remains one big question to answer: how did Brazil achieve such growth and results in a relatively short period of time? A discussion of the overall policies that have highly influenced this growth will address this issue in the case study below.

\section{CASE STUDY: MAIN BRAZILIAN POLICIES THAT WIDENED ACCESS TO HIGHER EDUCATION}

This section is divided into four parts. The first describes the numerical impact of privatisation of higher education in Brazil from 2002 to 2013; the second explains PROUNI, a scholarship programme funded by the government that supported access to university by low-income students; the third explains the impact of FIES, the government funded student loan policy; and the final section briefly cites several complementary initiatives that may have played a role in this transformation.

\section{THE PRIVATISATION OF HIGHER EDUCATION IN BRAZIL}

As indicated in section "The role of higher education in society", the beginning of the 1990s saw the World Bank recommend that LMICs like Brazil should focus on primary and basic education, and let the private provision of education auto-regulate the higher education system (World Bank, 1994). The political and economic conditions of Brazil led to a very limited amount of resources to invest, as seen in section "Brazil: overall educational context highlights". It was during the first half of his administration that one of the most important documents about the Brazilian higher education provision was created: PNE that defined goals and strategies to achieve the objectives of what was called the Education Decade (1996-2006).

The PNE was a document created by the MEC and approved in 1996 as a 10-year plan for education in Brazil. Among its key proposals, it is possible to identify the main foundations of the Brazilian expansion model (Dourado, 2002, p. 242-243):

- the establishment of national standardised exams to evaluate and rank universities;

- auditing and quality system controlled by the MEC;

- non-amplification of federal resources to invest in higher education;

- diversification of the higher education provision introducing private funding; and

- expansion of student credit using province funding (Dourado, 2002). 
The new quality system in place made it easier for the government to spot low level institutions and maintain a certain level of control in higher education; the lack of federal investment, incentives to student credit via municipal/province funding and the incentive to diversify funding in higher education opened space for private providers; the national ranking changed the way universities managed their resources and their goals.

Privatisation was then included as part of the system in three ways:

1. public provision with private funding (funding privatisation);

2. private provision with public funding (privatisation of provision); and

3. private provision with private funding (total privatisation) (Gentili, 2001, p. 75).

The presence of private higher education institutions in Brazil cannot be considered a recent phenomenon, since they are part of the market since the early decades of the XX century with the creation of the first Pontificia Universidade Católica (PUC) and there were periods (like during the early 70s) when the country experienced a boom of privately owned higher education institutions (Teixeira, 1989); however, due to the approval of the new legislation, a greater variety of institutions and funders was accepted within the sector, including the growth in investment coming from international for-profit educational groups in the sector (Martins, 2009).

The results were a boost in the number of private institutions, reaching the impressive number of $87.4 \%$ of all the higher education institutions as part of the private sector (INEP, 2012, p. 49). The growth in number of enrolments is also quite noticeable as seen in Graph 2.

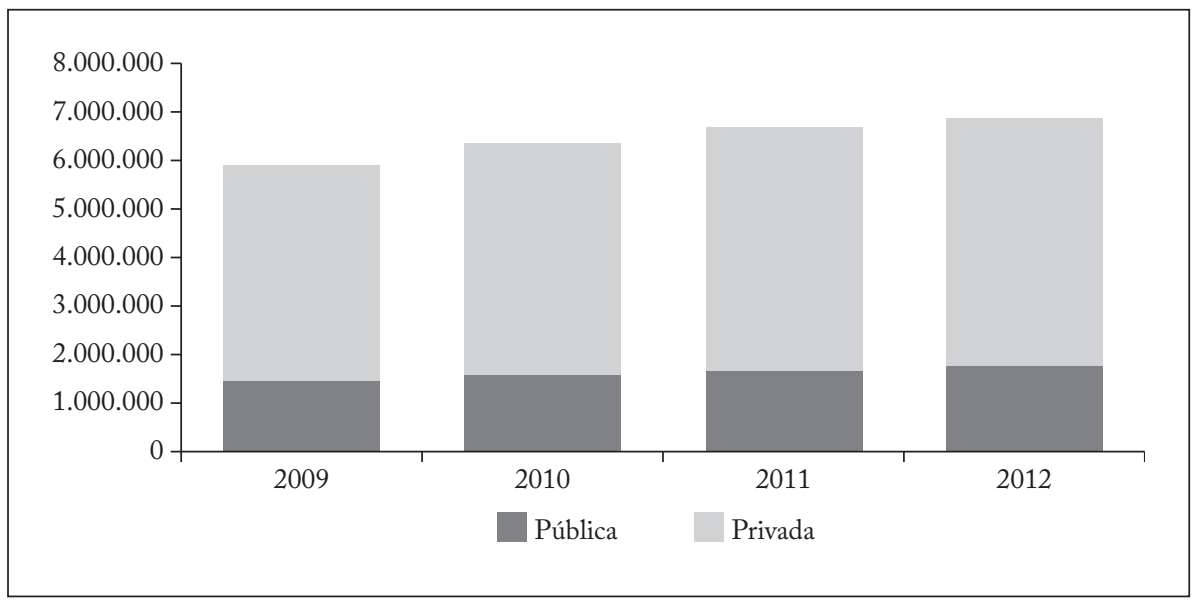

Graph 2 - Evolution of number of students enrolled in private and public higher education institutions Note: Dark green represents enrolment in public universities and light green in private institutions. Source: INEP (2012, p. 58).

Author's elaboration. 
Hence, the private provision represents more than two-thirds of all tertiary education degrees offered nationally (INEP, 2012, p. 79) and over three-quarters of all enrolments in 2012 (INEP, 2012). With a closer look at the nature of these private providers, another phenomenon can also be observed - especially in the recent decade: the rise in the number of number of students enrolling in universities owned by the biggest 8 private educational groups acting in the Brazilian market. This Group of 8 (Go8) consists mainly of multinational conglomerates with various operations, and the vast majority of them for profit. The Graph 3 showcases how influential these private providers are becoming:

The presence of these multinational groups might have various repercussions within the higher education sector that will be further discussed in detail in the last section of this article.

A last aspect that may be highlighted is that the privatisation movement does not simply coincide with the growth of for-profit institutions. As Ball (2007, p. 9) puts it, the movement of intense privatisation is also correlated with the one of "destatalisation", a shift in the role of state from funding to regulation, from provision of public services to reallocation of resources to supply the public needs. An example of this movement can also be recognised by the promulgation of

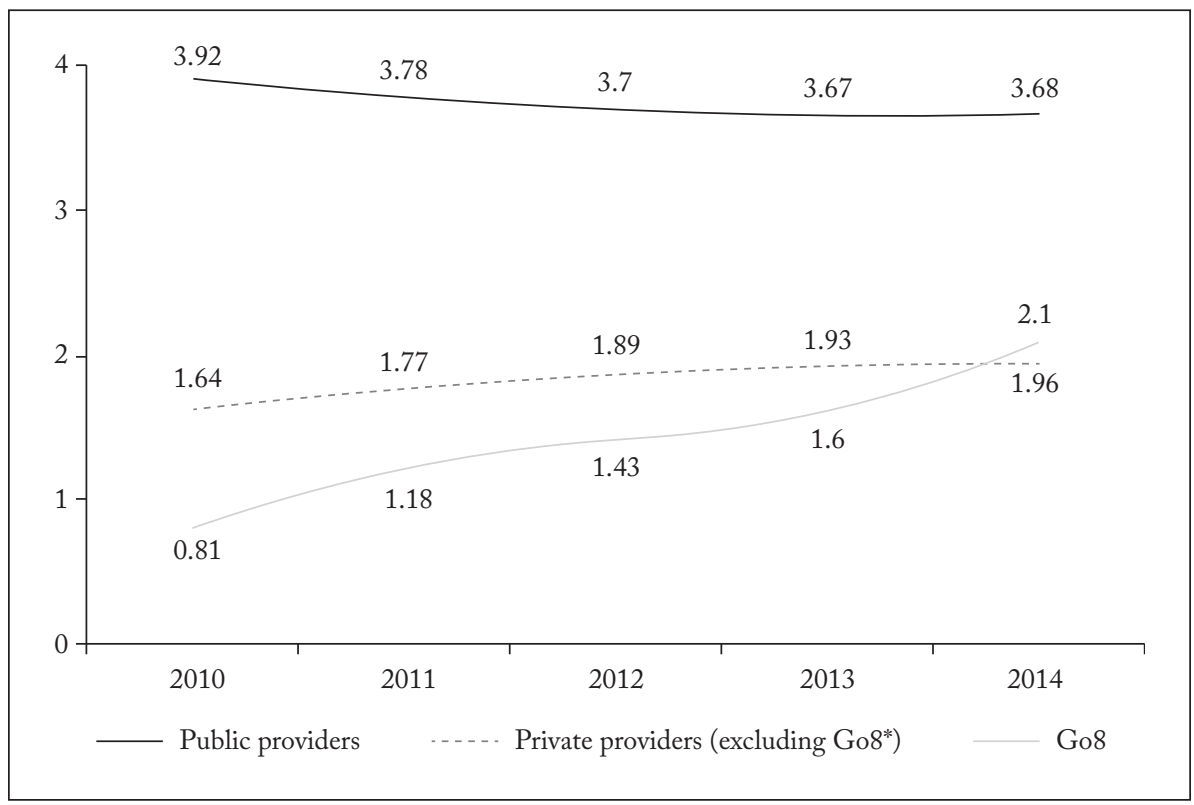

Graph 3 - Expansion of new students enrolled in higher education from 2010 to 2014 (in millions of students)

Note: The Go8 is formed by: Universidade Paulista (UNIP), Laureate International Universities, DeVry Education Group, Ser Educacional S.A., GAEC Educação S.A. (a.k.a. Grupo Ânima), Kroton Educacional S.A., Anhanguera Educacional S.A., Estácio Participações S.A. (a.k.a. Estácio de Sá).

Source: INEP (2016).

Author's elaboration. 
law n. 12.881 from the $12^{\text {th }}$ of November of 2013. This law officially recognised and ratified state-funding benefits for the Community Institutions of Higher Education, ${ }^{4}$ These are non-profit, autonomous higher education institutions that receive benefits and are eligible to receive a range of public funding initiatives, and are considered by the law "private institutions of public interest". Although these higher education institutions had been present in the Brazilian higher education sector since the 1940s, the official recognition of these institutions by the MEC, with a specific legislation and benefits lawfully protected, can be considered also a milestone in this privatisation movement. There were in 2016 over 60 institutions of this kind in Brazil accounting for over $20 \%$ of new student enrolments in a year, ${ }^{5}$ and these Community Institutions of Higher Education were praised by the MEC himself as indispensable for achieving the current Brazilian PNE's goal of widening participation in higher education; this factor can also be considered part of this movement of shifting public provision to privatisation.

\section{PROUNI AND THE STATE-FUNDED SCHOLARSHIPS}

As the last section indicates, the privatisation of higher education alone would not reduce its effects to the number of majors and institutions nationally; if, on the one hand, the 1996 PNE reinforced the fact that all public education in Brazil (either primary, secondary or tertiary) would be entirely free, including neither tuition fees nor any other administrative payment (Dourado, 2002, p. 240), it also became clear to the government that the lack of federal investments to increase the number of places offered in these institutions would require new funding and scholarships to avoid the exclusion of students from low-income backgrounds (Gentili, 2001).

Following a recommendation from the World Bank (1994, p. 34) that funding low-income students would be more feasible than opening new public universities, the federal government approved law n. 11.096 in 13 January 2005. The law established the PROUNI, a meritocracy-based scholarship system that funds up to $100 \%$ of total fees a student should pay to complete his first tertiary degree (PROUNI, 2015a). The allocation of scholarships is defined by the MEC in a selection process open to all Brazilian citizens twice per year, with a minimum score in the overall national entry exam (Exame Nacional do Ensino Médio ENEM) - the exam used by the majority of all universities to accept students. The maximum raw income of the family must be up to three minimum salaries (around $700 \mathrm{USD} / \mathrm{month} /$ person) for $50 \%$ funding and 1.5 minimum salaries for full scholarships (PROUNI, 2015a).

4 Author's own translation from the original Instituições Comunitárias de Educação Superior (ICES). In its majority, these act like standard universities granting 4 or 5 year bachelor and other higher education degrees; therefore, they are not intrinsically connected with the definition of community colleges in the United States, in example, although some might follow a similar purpose and principle.

5 Source: Associação Brasileira de Universidades Comunitárias (ABRUC). Available at: $<$ http://portal.mec.gov.br/component/tags/tag/34358>. Access at: $5^{\text {th }}$ Feb. 2018. 
In addition to these requirements, the student must fulfil one of the criteria below to be eligible for this scholarship:

- have concluded his/her secondary education in a public school;

- have concluded his/her secondary education in a private school as a student awarded a full scholarship;

- have concluded his/her secondary education with a mix of the two previous options;

- be a person with special needs; or

- be employed as a teacher of the public educational network.

Until 2013, the PROUNI initiative funded over 1.2 million students, with 1.116 private higher education institutions participating currently, and one scholarship awarded for each ten students enrolled in private institutions (PROUNI, 2015a).

\section{FIES AND STATE-FUNDED STUDENT LOANS}

Established in 1999 under the Cardoso administration, FIES is a student loan system organised by two banks the majority of whose funding derives from the state (Banco do Brasil and Caixa Econômica Federal), which provide students of private higher education institutions with an 18-month grace period and low interest rates (3.4\% per annum). In 2010, the period of time that students/graduates can take to pay back their loan was three times longer than the total of years the degree required (FIES, 2015b).

Although quite a common system in a range of different countries, FIES was an innovative strategy introduced in Brazil with huge impact. It is estimated that, in 2014,26\% of all students enrolled in private higher education institutions were benefitting from the loan system - with full or partial funding (FIES, 2015b), which represents an estimated investment of $\mathrm{R} \$ 13$ billion by the government (around 4.3 billion USD). ${ }^{6}$

Until the end of 2014, students would apply directly to FIES in partner higher education institutions and receive a confirmation according to the amount of resources available to partners and institutions recognised by the MEC; but in 2015 , new rules were introduced, including a minimum score in the national entry exam (ENEM), a centralised application system and a minimum quality index for the institutions and courses awarded with the benefit.

\section{LOW-INCOME/RACE-BASED QUOTAS FOR PUBLIC TERTIARY EDUCATION}

In 1997, Brazil had only $2.2 \%$ of brown-skinned and $1.8 \%$ of black-skinned people aged 18-24 years either enrolled in or graduated from college (INEP, 2003).

6 As of 14 May 2015 official currency (BRL-USD). 
Race inequality and the low number of vacancies available for low-income students (generally coming from public schools, with generally lower scores according to historical Pesquisa Nacional por Amostra de Domicílios - PNAD - evaluations) was creating a dangerous gap between different strata of society.

In 2004, the National University of Brasília (UnB) was the first federal institution to adopt a system of quotas to balance the number of ethnic and low-income populations in public universities. ${ }^{7}$ The movement was followed by several province-based and federal universities, until the approval of law n. $12.711^{8}$ in 2012, which determined that federal universities must reserve $50 \%$ of all its vacancies for students:

- $\quad$ self-declared as black-skinned, brown-skinned, Indian - following definitions used by IBGE, and/or

- low-income - with overall income equal or less than 1.5 minimum salary per capita; and/or

- who took their entire secondary education in a public school.

Despite protests and constant legal actions against the practice, the law is currently valid, and the number of brown-skinned either studying at or graduated from universities has grown from 2.2 to $11 \%$ and the number of black people followed this pattern has climbed from 1.8 to $8 \%{ }^{9}$ (INEP, 2012).

\section{DISCUSSION}

A first look at the case study clearly shows that the privatisation movement would be extremely affected if public policies that widened access had not been implemented. Given that $26 \%$ of all students in private universities use FIES (2015b) and almost 10\% of all private students are part of PROUNI (2015a) makes an undeniable argument that the number of participants and private higher education institutions would be considerably lower if the state had not intervened and increased the amount invested in higher education provision.

On the other hand, the amount invested by the government has reached unsustainable costs. That is the reason why the government announced changes in the FIES rules at the end of 2014, ${ }^{10}$ and president Dilma Rousseff declared publicly they had made a mistake in not centralising the system before and leaving it to be approved solely by the partner universities. ${ }^{11}$ The fact is that after

7 Available at: <http://revistaforum.com.br/digital/138/sistema-de-cotas-completa- dezanos-nas-universidades-brasileiras/>. Access at: $18^{\text {th }}$ May 2015.

8 Available at: <http://www.planalto.gov.br/ccivil_03/_ato2011-2014/2012/lei/112711. htm>. Access at: $18^{\text {th }}$ May 2015.

9 Data refers to young people aged from 18 to 24 years old.

10 Available at: <http://exame.abril.com.br/brasil/noticias/governo-dificulta-acesso-aofinanciamento-estudantil>. Access at: 11 May 2015.

11 Available at: <http:/g1.globo.com/educacao/noticia/2015/03/dilma-admite-erro-aodeixar-controle-do-fies-para-faculdades-particulares.html>. Access at: $11^{\text {th }}$ May 2015. 
lowering the interest rates from 6.5 per annum to $3.4 \%$ in 4 years, the amount the government was spending had multiplied 13 times and became a really profitable operation for private higher education institutions. Therefore, at the beginning of the year, the government had to confront 178 thousand prospective students angry and disappointed after seeing their hopes of joining university vanish with a deferred application; various riots across the country protested against the system's mismanagement. ${ }^{12}$

The main argument for privatisation is to widen access to higher education. In this sense, the increase in enrolment resulting from Brazilian public policies are undeniable; but have the number of low-income students risen during this period of time? The chart below in Graph 4 shows an interesting trend.

Despite the huge gap between the two groups, it is possible to observe that the average number of years in the low-income tier has grown three times as fast as the number of years in the high income tier (1.5 vs 0.5$)$. Although it is not possible to say that the low-income students are in tertiary education, it is possible to observe the likelihood that a gap in education between the poorest and the richest is reducing consistently is a highly reasonable option. The rising enrolment figures in the poorest regions of Brazil (previously presented on Table 2) are also another indicator that low-income participation is more likely

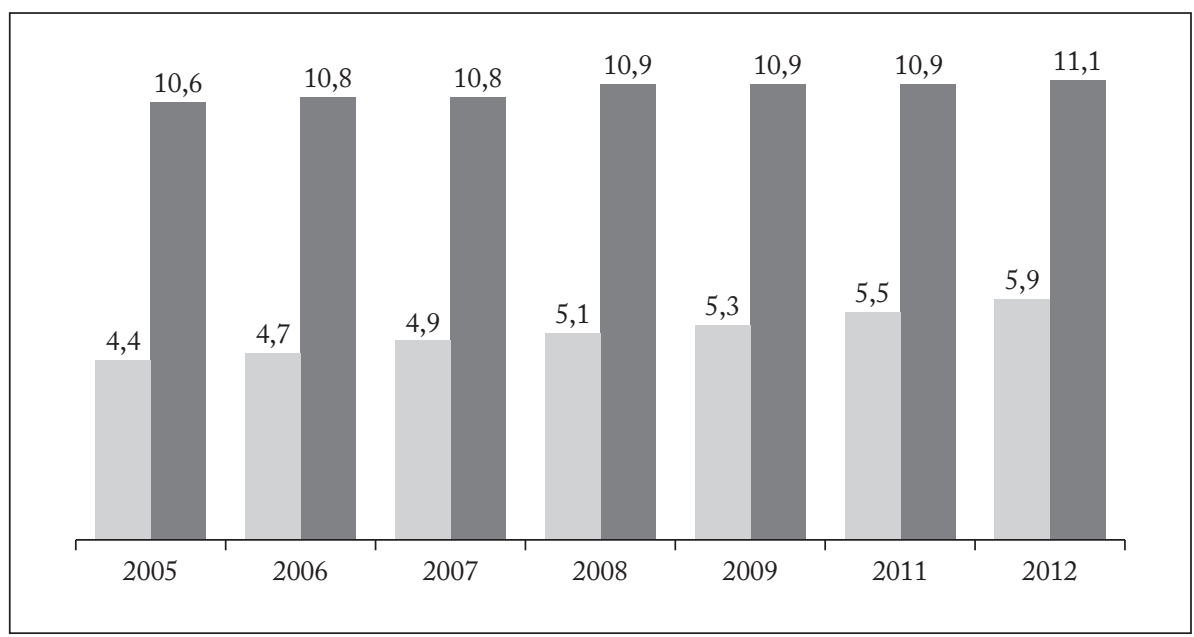

Graph 4 - Years of study $20 \%$ poorest students vs $20 \%$ richest

Note: Figures are given for the average number of study years of the population over 18; dark grey indicates the $20 \%$ richest students, while light grey corresponds to the $20 \%$ poorest students.

Source: INEP (2012, p. 42).

Author's elaboration.

12 Available at: <http://g1.globo.com/educacao/noticia/2015/05/178-mil-alunos-tentaramcontrato-do-fies-mas-nao-conseguiram-diz-mec.html>. Access at: $14^{\text {th }}$ May 2015. 
to participate in the overall results, and the same can be concluded by the notable variety in number of ethnic minorities in federal universities (see subsection "Low income/race-based quotas for public tertiary education"). Although the national percentage of enrolment in tertiary education is still quite below that of developed countries and even other LMICs (such as Argentina), it is possible to see consistent results.

Our discussion points to an immediate question regarding the effects of such huge expansion in a short period of time: the quality of education. Harland (2009, p. 519) claims that one of the key aspects of tertiary education is the ability to question authority, to innovate; while embracing the neoliberal perspective is to introduce subordination and control of the university according to market rules, that gradually begin to manipulate academics. The same author claims that the limits of neoliberalism must be delineated, as quite often the objectives of high quality higher education may be threatened by the reigning "for profit" orientation of companies (i.e., reducing the professor/ student ratio, basic infrastructure investments, employing temporary teachers instead of full time employees) (Harland, 2009 , p. 519). Schendel and McCowan (2015, p. 289) add that regulation of quality becomes difficult with the amount of political power concentrated in the hands of private groups.

McCowan (2004) argues about the desirability of such a pace of expansion. The author claims that despite the consistent results, there are several chronic problems with the educational system in Brazil:

- most institutions look like high schools, with poor infrastructure, uneven teaching quality and hourly or part-time staff;

- the growth of private provision has led to a new stratification of opportunity, with low budget universities providing low quality experiences for students, thereby multiplying the inequality cycle; and

- there are concerns over transfer of public funds for private institutions, especially as most of the universities described in this case study are "for profit" (Schendel and McCowan, 2015, p. 289).

These concerns are highly relevant to this study, and remain without a satisfactory answer; the gap between private provision and public universities is astonishing: out of the top-ranked universities in Brazil, less than $20 \%$ are private. ${ }^{13}$ Especially in the research-related indicators, public universities outrank the private universities by a large margin.

The same type of criticism has been directed at the quota system, with the addition that the meritocracy attached to the capitalist system is threatened by such an initiative. In fact, a study focused on a renowned public university in the Rio de Janeiro province (Universidade do Estado do Rio de Janeiro - UERJ) showed the

13 Available at: <http://www.topuniversities.com/latin-american-rankings>. Access at: $17^{\text {th }}$ May 2015. 
average entry exam score of students joining the quota system is typically considerably lower than the non-quota students (Table 3).

Although the results are quite different at entry level, an interesting phenomenon appears when we analyse the average academic score. The levels of achievement are relatively similar (Table 4).

Henceforth, although a single study is not enough to set a standard for the national average, at least it serves to discredit the argument that all quota students are fated to become incompetent professionals or low achieving students; in fact, it may mean that when students from different backgrounds are given a similar high-quality environment, their results can be similar. This cannot be cited as a conclusion, but could easily be a topic for further study.

\section{CONCLUSION}

Overall, the social inclusiveness and the fast pace of the higher education expansion in Brazil are undeniable; the World Bank recommendations, therefore, could fulfil the objectives of widening participation. However, the danger of an unregulated approach is a real threat to the quality and equity of the system.

As the last section shows, the constant clash between the "for profit" orientation and high-quality provision may be a threat for the basic infrastructure of higher education; concentrating power in the hands of for profit universities may be hazardous for political reasons; and not properly regulating standards for higher education institutions may represent a huge debt for the state. This may not be solely on a short-term basis like the FIES, but may also have long term effects for

Table 3 - Exam grades: quota vs non-quota students UERJ

\begin{tabular}{l|c|c}
\hline Major (Subject) & Quota & Non-Quota \\
\hline Management & 30.48 & 56.02 \\
\hline Law & 43.83 & 72.38 \\
\hline Chemical Engineering & 35.13 & 43.88 \\
\hline Medicine & 53.30 & 75.08 \\
\hline
\end{tabular}

Source: Bezerra (2011).

Author's elaboration.

Table 4 - Average academic performance quota vs non-quota

\begin{tabular}{l|c|c}
\hline Major (Subject) & Quota & Non-Quota \\
\hline Management & 8.077 & 8.044 \\
\hline Law & 7.71 & 8.57 \\
\hline Chemical Engineering & 6.68 & 7.18 \\
\hline Medicine & 7.46 & 7.607 \\
\hline
\end{tabular}

Source: Bezerra (2011).

Author's elaboration. 
the economy - keeping in mind that the objectives of higher education take an active role in diminishing inequalities and increasing productivity. A low-quality system will most likely only reverberate with the present inequalities of the system, stratifying even further the distance between the poorest and the richest individuals.

Finally, Brazil provides a unique opportunity to understand and assess the effects of higher education privatisation worldwide, as it is one of the fastest developing countries and one of the main exponents of the strong influence of private players in the educational sector.

\section{REFERENCES}

BALL, S. Education plc: understanding private sector participation in public sector education. London: Routledge, 2007.

Bezerra, T. O. C. A política de cotas em universidades e inclusão social: desempenho de alunos cotistas e sua aceitação no grupo acadêmico. 2011. 187p. Ph.D. (Thesis in Educación) - Universidad de la Empresa, Montevideo, 2011.

Brasil. Lei n. 12.711, de 29 de agosto de 2012. Dispõe sobre o ingresso nas universidades federais e nas instituições federais de ensino técnico de nível médio e dá outras providências. Diário Oficial da União, Brasília: DF, 30 ago. 2012.

. Lei n. 12.881, de 12 de novembro de 2013. Dispõe sobre a definição, qualificação, prerrogativas e finalidades das Instituições Comunitárias de Educação Superior - ICES, disciplina o Termo de Parceria e dá outras providências. Diário Oficial da União, Brasília: DF, 13 nov. 2013.

Dourado, L.F. Reforma do Estado e as políticas para a educação superior no Brasil nos anos 90. Educação E̋ Sociedade, Campinas: CEDES, v. 23, n. 80, p. 234-252, set. 2002. FIES - Fundo de Financiamento Estudantil. Financiamentos concedidos em 2.2015. Brasília, DF: MEC, 2015b. Disponível em: <http://www.fnde.gov.br/dadosabertos/ dataset/fundo-de-financiamento-estudantil-fies>. Acesso em: 5 fev. 2018.

Gentili, P. A falsificação do consenso: simulacro e imposição na reforma educacional do neoliberalismo. 2. ed. Petrópolis: Vozes, 2001.

Harland, T. The university, neoliberal reform and the liberal educational ideal. In: Tight, M. (Ed.). The Routledge international handbook of higher education. London: Routledge, 2009. p. 511-521.

Harris, S. Rethinking academic identities in neo-liberal times. Teaching in Higher Education, Oxford: Taylor and Francis, v. 10, n. 4, p. 421-433, 2005.

IBGE - Instituto Brasileiro de Geografia e Estatística. Censo demográfico 2010. Brasília, DF: 2010. Disponível em: <https:/www.ibge.gov.br/home/estatistica/populacao/ censo2010/aglomerados_subnormais_informacoes_territoriais/default_informacoes_ territoriais.shtm $\geq$. Acesso em: 5 fev. 2018.

IMF - International Monetary Fund. Redistribution, inequality and growth. [S.1.: s.n.]: 2014. Available in: <http://www.imf.org/external/pubs/ft/sdn/2014/sdn1402.pdf>. Access in: 18 $8^{\text {th }}$ May 2017. 
IMF - International Monetary Fund. Data report from April/2015. [S.1.: s.n.]: 2015. Available in: <http://www.imf.org/external/pubs/ft/weo/2015/01/weodata/ weorept. aspx? pr. $\mathrm{x}=83 \&$ pr. $\mathrm{y}=16 \& \mathrm{sy}=2015 \& \mathrm{ke}=2015 \& \mathrm{scs} \mathrm{m}=1 \& \mathrm{ssd}=1 \&$ sort $=$

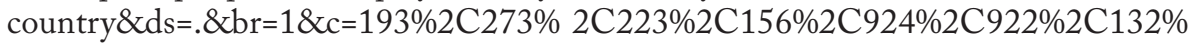
$2 \mathrm{C} 184 \% 2 \mathrm{C} 134 \% 2 \mathrm{C} 534 \% 2 \mathrm{C} 536 \% 2 \mathrm{C} 136 \% 2 \mathrm{C} 158 \% 2 \mathrm{C} 112 \% 2 \mathrm{C} 111 \% 2 \mathrm{C} 542 \& \mathrm{~s}=$ NGDPD\%2CPPPGDP\&grp=0\&a=>. Access in: 11 ${ }^{\text {th }}$ May 2017.

INEP - Instituto Nacional de Estudos e Pesquisas Educacionais. Resumo técnico censo da educação superior 2002. Brasília, DF: INEP, 2003. Disponível em: <http://download.inep. gov.br/download/superior/censo/tabelas_resumo_tec_xls>. Acesso em: 12 abr. 2017.

. Resumo técnico censo da educação superior 2012. Brasília: 2012. Disponível em: <http://download.inep.gov.br/download/superior/censo/2012/resumo_tecnico_censo_ educacao_superior_2012.pdf $\geq$. Acesso em: 15 maio 2017.

Resumo técnico censo da educação superior 2015. Brasília, DF: INEP, 2016. Disponível em: <http://download.inep.gov.br/informacoes_estatisticas/sinopses_ estatisticas/sinopses_educacao_superior/sinopse_educacao_superior_2015.zip >.Acesso em: 3 jul. 2017.

LEHER, R. O BIRD e as reformas neoliberais na educação. PUCVIVA, São Paulo: PUC, n. 5, p. 16-22, 1999.

Martins, C. B. A reforma universitária de 1968 e a abertura para o ensino superior privado no Brasil. Educação Ẽ Sociedade, Campinas: CEDES, v. 30, n. 106, p. 15-35, 2009. Mccowan, T. The growth of private higher education in Brazil: implications for equity and quality. Journal of Education Policy, London: Taylor \& Francis, v. 19, n. 4, p. 453-472, 2004.

OECD - Organisation for Economic Co-Operation and Development. PISA 2012 Technical Report. Paris: OECD, 2012. Available in: <http://www.oecd.org/pisa/ pisaproducts/pisa2012technicalreport.htm $\geq$. Access in: $7^{\text {th }}$ May 2017.

. Society at a glance. Paris: OECD, 2014. Available in: <http://www.keepeek. com/Digital-Asset-Management/oecd/social-issues-migration-health/society-at-aglance-2014_soc_glance-2014-en\#page1 2 . Access in: 10 $0^{\text {th }}$ Apr. 2017.

PNAD - Pesquisa Nacional por Amostra de Domicílios. Pesquisa Nacional por Amostra de Domicílios 2007. Brasília, DF: IBGE, 2007. Disponível em: <http://www.ibge.gov.br/ home/estatistica/populacao/trabalhoerendimento/pnad2007/graficos_pdf.pdf $>$. Acesso em: 5 maio 2017.

Pesquisa Nacional por Amostra de Domicílios 2008. Brasília, DF: IBGE, 2008. Disponível em: <http://www.ibge.gov.br/home/estatistica/populacao/ trabalhoerendimento/pnad2008/>. Acesso em: 6 maio 2017.

PROUNI - Programa Universidade para Todos. Base de dados. Brasília, DF: MEC, 2015a. Disponível em: <http://prouni.mec.gov.br/o_prouni.php $\geq$. Acesso em: 10 dez. 2015.

Rawls, J. A theory of justice. Oxford: Oxford University Press, 1999.

Schendel, R.; McCowan, T. Higher education and development: critical issues and debates. In: McCowan, T.; Unterhalter, E. (Eds.). Education and international development: an introduction. London: Bloomsbury, 2015. p. 275-293. 
Teixeira, A. Ensino superior no Brasil: análise e interpretação de sua evolução até 1969. Rio de Janeiro: Fundação Getúlio Vargas, 1989.

UN - United Nations. Universal Declaration of Human Rights. New York: 1948. Available in: <http://www.un.org/en/documents/udhr/ >. Access in: $19^{\text {th }}$ April 2017.

UNESCO - United Nations Educational, Scientific and Cultural Organization. Youth and skills: putting education to work. Paris: UNESCO, 2012. Available in: $<$ http://en.unesco.org/gem-report/report/2012/youth-and-skills-putting-educationwork\#sthash.K9b2I75M.dpbs $\geq$. Access in: 1th May 2017.

World BAnk. The World Bank Annual Report. Washington, DC: 1994. Available in: $<$ http://www-wds.worldbank.org/external/default/WDSContentServer/WDSP/IB /1994/08/01/000009265_3970716142209/Rendered/PDF/multi0page.pdf $\geq$. Access in: 30 ${ }^{\text {th }}$ April 2017.

. The World Bank Annual Report. Washington, DC: World Bank, 2011.

. World Bank database. Washington, DC: Word Bank, s.d. Available in: $<$ http://databank.worldbank.org/data/reports.aspx?Code=SE.TER.ENRR\&id= c755d342\&report_name=EdStats_Indicators_Report\&populartype $=$ series $>$. Access in: $5^{\text {th }}$ Feb. 2018.

\section{ABOUT THE AUTOR}

Leonardo Civinelli Tornel da Silveira is a Ph.D. candidate in adult education at Universidade de Lisboa (Portugal).

E-mail: leotornel@gmail.com

Received on July 28, 2017

Approved on December 10, 2017 